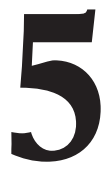

\title{
VALIDATION OF A SCALE OF ATTENTION TO DIVERSITY FOR UNIVERSITY TEACHERS
}

\author{
(VALIDACIÓN DE UNA ESCALA DE ATENCIÓN A LA DIVERSIDAD PARA \\ PROFESORADO UNIVERSITARIO)
}

Genoveva Ramos Santana

Amparo Pérez Carbonell

Inmaculada Chiva Sanchis

Ana María Moral Mora

Universitat de València

DOI: $10.5944 / e d u c X X 1.28518$

\section{How to reference this article/Cómo referenciar este artículo:}

Ramos Santana, G., Pérez Carbonell, A., Chiva Sanchis, I., \& Moral Mora, A., (2021). Validation of a scale of attention to diversity for university teachers. Educación XX1, 24(2), 121-142. https://doi. org/10.5944/educXX1.28518

Ramos Santana, G., Pérez Carbonell, A., Chiva Sanchis, I., y Moral Mora, A., (2021). Validación de una escala de atención a la diversidad para profesorado universitario. Educación XX1, 24(2), 121-142. https://doi.org/10.5944/educXX1.28518

\begin{abstract}
It is the job of universities to face the greatest challenges of higher education in the twenty-first century. Creating policies and practices to attend to diversity is part of their social responsibility. Validated instruments are essential to find out teachers' attitudes and practices in education regarding attention to diversity. This paper aims to present the process of construction and validation of the Scale of Beliefs, Attitudes and Practices of Attention to Diversity for University Teachers (CAPA-PU) created for this purpose. A survey method with a non-experimental design was applied to a sample of 428 teachers from various Spanish universities. To validate this scale, analysis of the content and construct preceded the selected items in the ad hoc instrument in order to reach the representativeness of the construct. A review of the literature on attention to diversity, especially instrument design, informed
\end{abstract}


of the definition of the construct and its dimensions, representativeness, relevance, comprehension, ambiguity and clarity. In addition, reliable internal consistency and exploratory and confirmatory factor analysis showed a fitted model and a five-factor structure: (1) Institutional Diversity; (2) Research, Training and Teaching Focused on Diversity; (3) Teaching and Learning Practices; (4) University Administrators' Commitment; (5) Conception of Diversity. In conclusion, it is evident that there is: a) current relevance of the assumed construct of attention to diversity focused on actions that provide learning opportunities to the most disadvantaged groups; and b) the need to offer a scale such as the one created in order to attend to the processes of educational inclusion in Spanish universities.

\section{KEYWORDS}

Higher education, teacher, diversity, scales, measurement, validity

\section{RESUMEN}

Es tarea de las universidades afrontar los grandes retos de la educación superior del siglo XXI creando políticas y prácticas de atención a la diversidad como parte de su responsabilidad social. Por lo que se hace imprescindible contar con instrumentos validados para conocer las actitudes y prácticas educativas en atención a la diversidad desarrolladas por el profesorado de estas instituciones. Este artículo tiene como objetivo presentar el proceso de construcción y validación de la Escala de Creencias, Actitudes y Prácticas de Atención a la Diversidad (CAPA-PU) para Profesorado Universitario elaborada para tal fin. Esta ha sido aplicada, siguiendo un método de encuesta con un diseño no experimental, a una muestra de 428 docentes de varias universidades españolas. Para la validación de la escala se ha procedido al análisis de contenido y de constructo de los ítems seleccionados en el instrumento construido ad hoc con el fin de lograr la representatividad de los mismos sobre el constructo a medir. La revisión por parte de personas expertas en atención a la diversidad y en diseño de instrumentos informó de la definición del constructo y sus dimensiones, de su representatividad, relevancia, comprensión y claridad. El análisis de fiabilidad -como consistencia interna- y los estudios factoriales realizados -Exploratorio y Confirmatorio, muestran un modelo ajustado y una estructura de cinco factores: (1) Diversidad institucional; (2) Investigación, formación y docencia en atención a la diversidad; (3) Prácticas de enseñanzaaprendizaje; (4) Compromiso de las personas que lideran; (5) Concepción de diversidad. En conclusión, se hace patente: a) la relevancia actual del constructo de atención a la diversidad asumido y centrado en las actuaciones que permiten dar oportunidades de aprendizaje a aquellos grupos más desfavorecidos; y b) la necesidad de ofrecer una escala, como la elaborada, para atender a los procesos de inclusión educativa en las universidades españolas. 
GENOVEVA RAMOS SANTANA, AMPARO PÉREZ CARBONELL, INMACULADA CHIVA SANCHIS, ANA MARIA MORAL MORA

VALIDATION OF A SCALE OF ATTENTION TO DIVERSITY FOR UNIVERSITY TEACHERS

\section{PALABRAS ClAVE}

Educación superior, docente, diversidad, escalas, medición, validez

\section{INTRODUCTION}

An inclusive university is one that welcomes diversity as an attitude and value on the rise (Martins et al., 2018). Encouraged by its contribution to the Sustainable Development Goals (SDG) set forth in the 2030 Agenda, an inclusive university seeks to ensure quality education by promoting learning opportunities for all and ensuring access to equal conditions according to the diversity of capacities that are present in society (CERMI, 2019; Chien et al., 2017; Montero, et al., 2019). An inclusive university strives to know and learn essential methodological and curricular modifications not for the purpose of offering advantages, but to ensure equality to a diverse student body, thereby avoiding discrimination in the academic setting (Bowles \& Brindle, 2017; Yu \& Zhang, 2016). It embraces diversity in the organisational culture as a whole and, in particular, its educational policies and practices in the institution (Ainscow, 2016; García et al., 2017; McMahon et al., 2016). A more humane university is needed, where all identities and viewpoints are appreciated and not just tolerated, where all people feel integrated and take an active role (Fundación Universia, 2018; Márquez \& Sandoval, 2019).

From this context, we regard inclusion in education as a continuous process in the search for effective answers to student diversity and where diversity itself becomes a stimulus for learning (UNESCO, 2016). According to CERMI (2019), this process should be developed with the collaboration of the educational community as a whole through the collective effort led by the Administrations, which are ultimately responsible, so that the entire education structure can achieve this inclusion. In other words, attention to diversity applied to the inclusive educational model can offer every student the adjustments needed to facilitate participation in the full learning process. Therefore, universities should propose schemes for attention to diversity that provide essential access opportunities to all disadvantaged groups (students with a disability, immigrants, cultural minorities, socioeconomically disadvantaged groups, LGBTI...). Likewise, strategies are needed to ensure participation and progress, preventing any type of discrimination or excluding circumstance (García et al., 2017; O'Donnell, 2016). Actions should be systematised from the following levels.

\section{Level 1. Institutionalisation of attention to diversity}

Moving towards inclusive systems is a slow, highly complex process. It implies the inevitable transformation of policies, structures and institutional 
practices (Márquez \& Sandoval, 2019; Toboso et al., 2019). Despite the publication of national and international documents highlighting the need to assume a social model advocating the application of inclusive measures in the academic setting (ONU, 2018), there is still no encouraging response in the context of education (Echeita, 2017; McNair, 2016; ONU, 2018). Some studies (Moliner et al., 2019) demonstrate that universities, on occasion, are insufficiently prepared to include all students from an inclusive standpoint. In Spain, available statistics indicate a high percentage of educational inclusion, but it has been observed that there is an underlying discriminatory structural pattern of exclusion and segregation towards students with disabilities. This is based exclusively on a medical perspective, which significantly affects students with an intellectual or psychosocial disability and students with multiple disabilities (ONU, 2018). Thus, it becomes inevitable to dig deeper into the creation of proposals for the institutionalisation of attention to diversity aimed at coordinating the perspectives of the entire intervening community from a socio-critical and innovative vision (García et al., 2017; Muntaner Guasp et al., 2016; Toboso et al., 2019). The role of the Network of Support Services for Persons with Disabilities at the University is essential since it consolidates the need to provide support and accompaniment to ensure equal opportunities to students with disabilities (Rodríguez \& Arroyo, 2017).

\section{Level 2. Classroom context}

"Diversity is an integral part of the learning experience" (LePeau, Hurtado \& Davis, 2018, p. 127) and we must work to identify those forms or modes that allow us to include it in the classroom. It is important for teachers to do the following: attend to diversity and reflect on how it can be applied in the classroom; design and implement inclusive teaching methodologies that provide individual and group-based learning opportunities; use methodologies focused on curricular flexibility, including cooperative learning in networks, projectbased learning, and service learning; monitor the learning process of students by promoting actions that lead to greater autonomy; offer flexible assessment systems with the emphasis on continuous evaluation and self-assessment; design and implement educational materials in diverse formats and in digital formats that meet the criteria of representational multimodality (Feltrero, 2012) with materials based on the Universal Design for Learning principles (Benítez et al., 2019; Márquez \& Sandoval, 2019).

\section{Level 3. University teacher training}

Ongoing teacher training and guidance are essential so that their practices, materials and work spaces respect universal accessibility criteria (Toboso et al., 2019). In addition, teachers' attitudes regarding inclusion and attention to diversity are strongly conditioned by factors such as the lack of awareness of 
different types of diversity and lack of preparation for this (Álamo, 2018; Moriña, 2017). Simón and Carballo (2019) claim that teachers themselves identify the limitations they experience when trying to meet the educational needs of certain students. Not only do teachers recognise shortcomings in their training to develop inclusive educational practices, but also in other aspects such as university regulations and support services for attention to diversity (García et al. 2018). According to Fundación Universia (2018), students with disabilities require the following from universities and teaching staff: more teacher training on disabilities; more inclusion training; knowledge on how to proceed when dealing with students who have special needs; the need to change certain attitudes and prejudices; as well as greater empathy, understanding, involvement and sensibility.

In line with some studies (González et al., 2013), we believe the design of reliable, valid questionnaires and scales is essential to identify teachers' beliefs, attitudes and practices when it comes to diversity. An objective standpoint is required in order to gather relevant, useful information that enables the transformation of educational practices and the design of training schemes. Thus, this paper presents the design and construction of the scale that measures Beliefs, Attitudes and Practices of Attention to Diversity for University Teachers (CAPA-PU).

\section{MATERIALS AND METHODS}

\section{Participants}

Faculty members from the Spanish universities involved in the InclUni Project participated in the validation process of the CAPA-PU scale. A total of 428 teachers voluntarily responded to the online questionnaire designed to validate the scale. More specifically, we chose a simple random sampling process. The data collection effort started in September 2019, with prior consent from the governing bodies of each of the universities participating in the project. Then, each university shared the scale and asked for the voluntary participation of their teaching staff.

Teachers had a mean age of $50(\sigma=31.04)$, although the age range was between 24 and $68 ; 44.40 \%$ male and $55.60 \%$ female. The majority were civil servants $(44.30 \%)$ and contracted personnel $(39.0 \%)$, with an average length of service at university institutions of 15 years $(\sigma=10.99)$.

\section{Design}

A non-experimental quantitative survey was designed and the Classical Test Theory was used to validate the scale. Both the functioning of the items and 
the functioning of the scale as a whole (reliability coefficient, validity and its factorial structure) were analysed. Process followed, the elaboration of scales, by other studies both in the field of diversity and others related to education (Arias et al., 2016; Castro et al., 2017; Llorent \& Álamo, 2016, 2019).

\section{Instrumentation}

Data was gathered with an ad hoc instrument we designed, which was selfadministered with the application of an open source survey, LimeSurvey. The initial scale items were extracted from the following documents:

- Campus Survey of Faculty and Student Perceptions of Persons with Disabilities (Baker et al., 2012).

- Committing to equity and inclusive excellence. A Campus Guide for Self-Study and Planning (American Association of Colleges and Universities, 2015).

- Self-Assessment Rubric for the Institutionalization of Diversity, Equity, and Inclusion in Higher Education (NERCHE, 2016).

- The Ford Foundation Campus Diversity Initiative Survey of Voters on Diversity in Education and an Interview with Edgar Beckham (Ford Foundation, 1999).

From those, a selection was made of a total of 48 items that sought to make teachers reflect on their beliefs, attitudes and practices of attention to diversity. The method chosen for revising the content validity of the CAPA-PU was the calculation of descriptors to determine the validity index, obtained from the assessment of 15 experts: five specialists in attention to diversity with two publications in prestigious journals, four in educational measurement and assessment, and six university teachers with sample characteristics similar to the respondents. With a 4-point Likert scale, they rated the following (Abal et al., 2017): representativeness, relevance, adequacy, understanding, ambiguity and clarity of the items. After analysing the agreement, the 24-item instrument targeted at university teachers was created.

\section{Statistical analysis}

Different statistical analyses were carried out using the Statistical Package for the Social Sciences (SPSS) v. 24 and the Structural Equation Modelling Software (EQS) v. 6.1. Firstly, descriptive analyses of the sample and exploratory factor analysis (EFA) of the set of 24 items were conducted with half of the sample using the method of extraction of the principal components with Varimaz 
rotation and Kaiser criteria to check the adequacy and pertinence of dimensional analysis of all variables. Subsequently, in order to determine the adequacy of the scale, confirmatory factor analysis (CFA) was performed with the teachers' responses that were not used in the exploratory analysis and the root mean square errors (RMSE) (Tanaka \& Huba, 1989). Analysis carried out without prior knowledge of the number of factors to be studied or the relationship among them demonstrated that prior exploratory analysis was appropriate for subsequent confirmation. In addition, both factor analyses were done with two sub-samples that were unlike the study sample and the items with factor loads below .40 were eliminated.

\section{RESULTS}

\section{Descriptive statistics}

The 5-point Likert response scale was chosen; therefore, the items selected are responses that are equal or greater to 2.5 on average in which the teachers showed greater conformity with the statement (see Table 2). In general, high values appear in the response, which leads us to think that such teachers have a clear willingness to engage in a process of attention to institutional diversity. What's more, apart from items 17 and 18, the majority of the items demonstrate a negative bias and a kurtosis with mostly negative values - fifteen out of a total of twenty-four - all of which have values under 3.0, except for item 6. This meets the criteria for normality according to Chou \& Bentler (1995), which can be seen in Table 1.

Table 1

Mean, Standard Deviations, Asymmetry, and Kurtosis of the Beliefs, Attitudes and Practices of Attention to Diversity

\begin{tabular}{|c|c|c|c|c|c|}
\hline & Item & Mean & $\begin{array}{c}\text { Standard } \\
\text { deviations }\end{array}$ & Asymmetry & Kurtosis \\
\hline 1 & $\begin{array}{l}\text { The concept of diversity means } \\
\text { different ethnicity, race, } \\
\text { nationality or culture }\end{array}$ & 3.75 & 1.31 & -.95 & -.19 \\
\hline 2 & $\begin{array}{l}\text { The concept of diversity means } \\
\text { people with different thoughts } \\
\text { or ideas }\end{array}$ & 3.74 & 1.34 & -.91 & -.38 \\
\hline 3 & $\begin{array}{l}\text { The concept of diversity means a } \\
\text { different level of education }\end{array}$ & 3.04 & 1.52 & -.16 & -1.46 \\
\hline 4 & $\begin{array}{l}\text { The education system should } \\
\text { place greater emphasis on } \\
\text { learning about other groups (...) }\end{array}$ & 3.77 & 1.21 & -.71 & -.43 \\
\hline
\end{tabular}




\begin{tabular}{|c|c|c|c|c|c|}
\hline & Item & Mean & $\begin{array}{c}\text { Standard } \\
\text { deviations }\end{array}$ & Asymmetry & Kurtosis \\
\hline 5 & $\begin{array}{l}\text { Diversity, inclusion and } \\
\text { equity are an essential part of } \\
\text { education that should be taught } \\
\text { at all educational institutions }\end{array}$ & 4.37 & .96 & -1.75 & 2.95 \\
\hline 6 & $\begin{array}{l}\text { Diversity, inclusion and equity } \\
\text { are an institutional but also } \\
\text { individual matter... }\end{array}$ & 4.37 & .9 & -1.83 & 3.69 \\
\hline 7 & $\begin{array}{l}\text { One of the purposes of } \\
\text { university institutions is to train } \\
\text { students to manage in a more } \\
\text { diverse society }\end{array}$ & 4.30 & .99 & -1.77 & 2.49 \\
\hline 8 & $\begin{array}{l}\text { One of the purposes of } \\
\text { university institutions is to train } \\
\text { students to manage in a more } \\
\text { diverse job market }\end{array}$ & 4.16 & 1.0 & -1.34 & 1.50 \\
\hline 9 & $\begin{array}{l}\text { University curricula should } \\
\text { include specific material on the } \\
\text { role of women and minorities } \\
(\ldots)\end{array}$ & 3.49 & 1.32 & -.49 & -.84 \\
\hline 10 & $\begin{array}{l}\text { It is as important for universities } \\
\text { to prepare students to be } \\
\text { successful in a diverse world as } \\
\text { it is to prepare them to have } \\
\text { technical or academic skills }\end{array}$ & 4.01 & 1.0 & -1.17 & 1.07 \\
\hline 11 & $\begin{array}{l}\text { I believe universities should } \\
\text { develop specific schemes to } \\
\text { ensure diversity in the student } \\
\text { body }\end{array}$ & 4.00 & 1.1 & -1.18 & .96 \\
\hline 12 & $\begin{array}{l}\text { In general, the university } \\
\text { administrators promote schemes } \\
\text { for attention to diversity }\end{array}$ & 3.61 & .95 & -.65 & .59 \\
\hline 13 & $\begin{array}{l}\text { In my faculty or university there } \\
\text { is a solid trend towards diversity } \\
(\ldots)\end{array}$ & 3.38 & 1.0 & -.32 & -.05 \\
\hline 14 & $\begin{array}{l}\text { I develop research that in form } \\
\text { and/or content reflects my } \\
\text { commitment to diversity }(. . .)\end{array}$ & 3.22 & 1.41 & -.29 & -1.15 \\
\hline 15 & $\begin{array}{l}\text { In my research designs I include } \\
\text { elements that promote diversity } \\
(\ldots)\end{array}$ & 3.24 & 1.35 & -.33 & -1.0 \\
\hline 16 & $\begin{array}{l}\text { My university offers training } \\
\text { courses related to diversity }(\ldots)\end{array}$ & 3.55 & .99 & -.27 & -.36 \\
\hline
\end{tabular}




\begin{tabular}{|c|c|c|c|c|c|}
\hline & Item & Mean & $\begin{array}{c}\text { Standard } \\
\text { deviations }\end{array}$ & Asymmetry & Kurtosis \\
\hline 17 & $\begin{array}{l}\text { I participate in educational } \\
\text { innovation projects whose } \\
\text { objectives explicitly reflect } \\
\text { commitment to diversity (...) }\end{array}$ & 2.81 & 1.44 & .08 & -1.32 \\
\hline 18 & $\begin{array}{l}\text { I design teaching innovation } \\
\text { projects that specifically } \\
\text { incorporate issues of attention } \\
\text { to diversity }(\ldots)\end{array}$ & 2.63 & 1.41 & .25 & -1.24 \\
\hline 19 & $\begin{array}{l}\text { I invest my time and effort in } \\
\text { educational practices that } \\
\text { promote skills that lead to } \\
\text { success for all my students }\end{array}$ & 3.93 & 1.12 & -1.1 & .62 \\
\hline 20 & $\begin{array}{l}\text { I design and subsequently } \\
\text { monitor my teaching objectives } \\
\text { focused on equity }\end{array}$ & 3.26 & 1.34 & -.37 & -.95 \\
\hline 21 & $\begin{array}{l}\text { I provide support to } \\
\text { help students to develop } \\
\text { individualised plans }(. . .)\end{array}$ & 3.88 & 1.11 & -.87 & .06 \\
\hline 22 & $\begin{array}{l}\text { I incorporate multiple } \\
\text { methodologies to attend to } \\
\text { diversity... }\end{array}$ & 3.62 & 1.17 & -.63 & -.39 \\
\hline 23 & $\begin{array}{l}\text { I offer resources to support } \\
\text { the development of inclusive } \\
\text { teaching (...) }\end{array}$ & 3.63 & 1.45 & -.70 & -.15 \\
\hline 24 & $\begin{array}{l}\text { In my subjects, I use digital } \\
\text { learning and cooperative } \\
\text { activities to promote learning } \\
(\ldots)\end{array}$ & 3.66 & 1.20 & -.66 & -.41 \\
\hline
\end{tabular}

\section{Exploratory factor analysis}

Exploratory factor analysis that is recommended to assess the construct validity isolated 5 factors, suggesting a fitted, consistent model in which the initial theoretical size was reduced (see Table 3 ). The KMO value ranges between .80 and .90 and Bartlett's statistics show significant results above level .001 , which indicated that a good fit exists for factor analysis. The factor solution with the best fit is shown in Table 2. It shows the sample distribution of the 24 items in 5 factors and all with loading greater than .40 . The factors that explain $68.13 \%$ of the variance were:

I) Institutional Diversity: they comprise the teacher's perceptions regarding the social value of diversity as well as the proposals and actions carried out by universities to attend to diversity. 
II) Research, Training and Teaching Focused on Diversity: they refer to participation and research design; teacher training and organisation to attend to diversity.

III)Diverse Teaching and Learning Practices: educational practices that the teachers carry out in the classroom to attend to diversity.

IV) University Administrators' Perceived Commitment to Attention to Diversity: perception that the teachers have regarding actions taken by university administrators to attend to diversity.

V) Conception of Diversity: the meaning that teachers give to diversity.

Table 2

Rotated Factor Structure of the CAPA-PU Scale. Communalities and Cronbach's Alpha

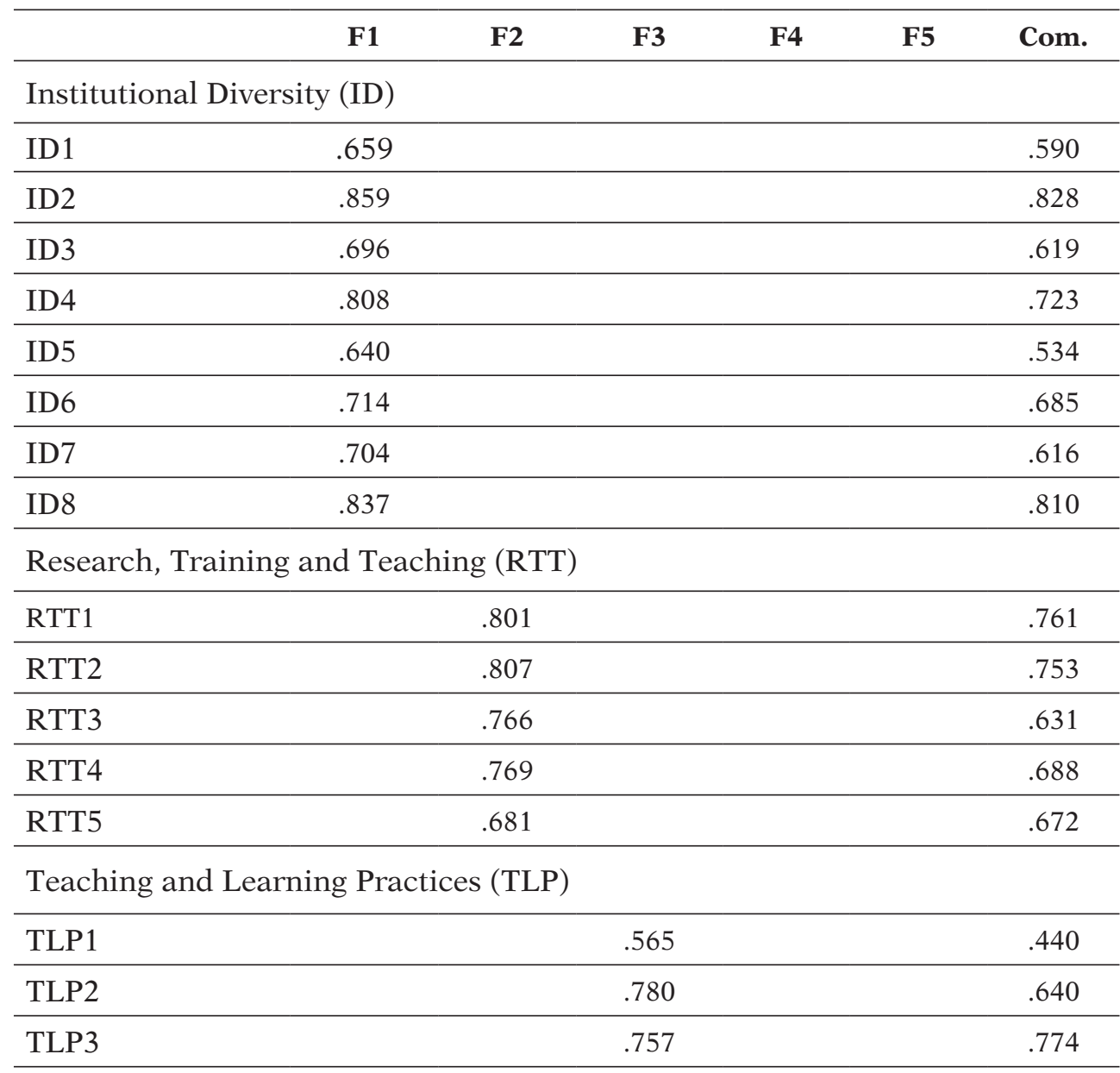


GENOVEVA RAMOS SANTANA, AMPARO PÉREZ CARBONELL, INMACULADA CHIVA SANCHIS,

\begin{tabular}{|c|c|c|c|c|c|c|}
\hline & F1 & F2 & F3 & F4 & F5 & Com. \\
\hline TLP4 & & & .813 & & & .791 \\
\hline TLP5 & & & .721 & & & .681 \\
\hline \multicolumn{7}{|c|}{ University Administrators' Commitment (UAC) } \\
\hline LC1 & & & & .870 & & .812 \\
\hline LC2 & & & & .830 & & .730 \\
\hline LC3 & & & & .752 & & .601 \\
\hline \multicolumn{7}{|c|}{ Conception of Diversity (CD) } \\
\hline CD1 & & & & & .754 & .639 \\
\hline CD2 & & & & & .783 & .649 \\
\hline CD3 & & & & & .819 & .683 \\
\hline Cronbach's alpha & .902 & .891 & .863 & .776 & .731 & \\
\hline Number of items & 8 & 5 & 5 & 3 & 3 & \\
\hline Explained variance & $20.18 \%$ & $16.06 \%$ & $14.08 \%$ & $9.50 \%$ & $8.40 \%$ & \\
\hline $\begin{array}{l}\text { Total explained } \\
\text { variance }\end{array}$ & \multicolumn{6}{|c|}{$68.10 \%$} \\
\hline $\begin{array}{l}\text { Total Cronbach's } \\
\text { alpha }\end{array}$ & \multicolumn{6}{|c|}{.897} \\
\hline Kaiser-Meyer-Olkin & \multicolumn{6}{|c|}{.86} \\
\hline
\end{tabular}

\section{Confirmatory factor analysis}

The goodness-of-fit indices of the five-factor model indicated on the scale demonstrate a good fit of the model with the empirical data in Table 4. However, to achieve this, we proceeded to item elimination and the confirmation of some of the factors by carrying out 9 tests of possible combinations. The following items were definitively eliminated: item 4 "The education system should place greater emphasis on learning about other groups (...)"; item 7 "One of the purposes of university institutions is to train students to manage in a more diverse society"; item 8 "(...) train students to manage in a more diverse job market"; item 17 "I participate in educational innovation projects whose objectives explicitly reflect commitment to diversity..."; and item 19 "I invest my time and effort in educational practices that promote skills that lead to success for all my students". Items that were found in different factors: 4,7 and 8 were found in the Institutional Diversity factor; item 17 in the Research, Training and Teaching factor and item 19 in the Teaching and Learning Practices factor. Following Tomas and Oliver (1998), a series of indices were then calculated as a whole, such as the root mean square error 
of approximation (RMSEA); goodness-of-fit indices: GFI, AGFI and PGFI; and indices that use the standard independence model as a basis for comparing NFI, relative fit index (RFI), non-normed fit index (NNFI) and comparative fit index (CFI). From an analytical perspective, factor saturations and the percentage of variance explained for each item were compared. There was an estimation of reproducibility coefficients, defined as the quotient between the saturations being compared. Table 3 shows the values that provide information on the goodness-of-fit, demonstrating both the first test and the last (ninth) test, reached from combinations of different items that were eliminated. In the second part of Table 3, the Chi square is shown to be significant for the model and its standard value is below the recommended cutoff value of less than 3 (Bollen, 1989). The RMSEA indicate a reasonable fit which was less than 0.08 (Browne \& Cudeck, 1992), as well as the values of NNFI, CFI and IFI exceeding the recommended cutoff value and shown to be close to unity (>.90) (Loehlin \& Beaujean, 2017).

Table 3

Goodness-of-fit ( $1^{\text {st }}$ test and $9^{\text {th }}$ test)

\begin{tabular}{|c|c|c|c|c|c|c|c|}
\hline Model & S-B $\chi 2$ & df & $\begin{array}{c}\text { S-B } \chi^{2} \\
/ \mathbf{d f}\end{array}$ & RMSEA & CFI & IFI & NNFI \\
\hline 5 factors -24 items & 488.50 & 242 & 2.02 & $\begin{array}{c}.007(.067 \\
.086)\end{array}$ & .853 & .856 & .832 \\
\hline Model & $\mathrm{S}-\mathrm{B} \chi 2$ & df & $\begin{array}{c}\text { S-B } \chi^{2} \\
/ \mathrm{df}\end{array}$ & RMSEA & CFI & IFI & NNFI \\
\hline 5 factors -19 items & 221.33 & 142 & 1.56 & $\begin{array}{c}.041(.041 \\
.070)\end{array}$ & .938 & .940 & .926 \\
\hline
\end{tabular}

Note. $\mathrm{S}-\mathrm{B} \chi 2$ = Satorra-Bentler Scaled Chi-Square; $\mathrm{df}=$ Degrees of freedom; RMSEA= Root mean square error of approximation; CFI= Comparative Fit Index; IFI= Bollen's Incremental Fit Index and NNFI= Bentler-Bonett Non- Normed Fit Index

Regarding the revision of reliability of each of the five factors (see Table 4), Cronbach's alpha values are shown to be above the recommended value of .70 (Fornell \& Larcker, 1981). Likewise, construct reliability and the average variance extracted are also shown to be higher than those recommended by Bagozzi and Yi (1988), specifically at .50, which is adequate reliability. 
Table 4

Scale Reliability

\begin{tabular}{lccccc}
\hline & F1 & F2 & F3 & F4 & F5 \\
\hline AVE & .59 & .77 & .68 & .47 & .47 \\
\hline CR & .88 & .91 & .89 & .73 & .73 \\
\hline$\sqrt{ }$ AVE & .77 & .88 & .82 & .69 & .69 \\
\hline$\alpha$ & .871 & .862 & .886 & .714 & .730 \\
\hline
\end{tabular}

Note. $\mathrm{AVE}=$ Average variance extracted; $\mathrm{CR}=\mathrm{Composite}$ reliability; $\sqrt{ } \mathrm{AVE}=$ square root of the AVE; $\alpha=$ Cronbach's alpha

Finally, discriminant validity analysis was conducted with the calculation of correlations between the factors (see Table 5). All of the loading demonstrated values below the threshold that Kline (2005) recommends (.85) for each factor. Likewise, the Fornell and Larcker (1981) criterion is met, indicating that the square root of the AVE is always superior to each pair of calculated correlations.

Table 5

Correlations Between Factors

\begin{tabular}{llllll}
\hline & F1 & F2 & F3 & F4 & F5 \\
\hline F1 & .77 & & & \\
\hline F2 & .495 & .88 & & & \\
\hline F3 & .396 & .481 & .82 & & \\
\hline F4 & .264 & .204 & .248 & .69 & \\
\hline F5 & .370 & .175 & .184 & .075 & .69 \\
\hline
\end{tabular}

Note. F1= Institutional Diversity; F2 = Research, Training and Teaching Focused on Diversity; F3= Diverse Teaching and Learning Practices; F4= University Administrators' Commitment; F5= Conception of Diversity. The diagonal offers the values of $\sqrt{ }$ AVE

\section{DISCUSSION AND CONCLUSIONS}

Universities' compliance with social responsibility, among other issues, has led them to pay more and more attention to the implementation of inclusive policies and practices. As such, looking for tools to provide better information on diversity-related actions to the institutions and their faculty is, at the moment, an urgent necessity. 
Some studies (Fundación Universia, 2018; Moriña, 2017; Simón \& Carballo, 2019) stress the need for a shift in the faculty members' educational beliefs, attitudes and practices to advance towards more inclusive education. They explicitly state the importance to accept, respect and value difference, to train educators and make them more aware and understanding of the potential of inclusion, so they will be more curious and willing to accept change (Álamo, 2018; Hernández et al., 2018; Lombardi et al., 2011; Yuknis, 2015), because teaching actions - conditioned by the educator's expectations, attitudes, and training regarding the attention to diversity - facilitate or hinder inclusive university processes or practices (Rodríguez \& Álvarez, 2015).

Others point to the importance of developing diagnostic and evaluation scales to obtain useful information and transform education towards a model that addresses human diversity and cares for the most vulnerable individuals (Arias et al., 2016; Polo, 2017).

In our metric study, we have opted for a complementary methodological process, seeking to validate both content and context (Lizasoain et al., 2017). This enabled us to verify that the vast majority of the items in the scale have good statistical and substantive behaviour.

The factorial results provide a concise, validated scale made up of 19 items and five denominating factors: Institutional Diversity; Research, Teaching and Training Focused on Diversity; Diverse Teaching and Learning Practices; University Administrators' Perceived Commitment to Attention to Diversity; and Conception of Diversity.

- We conclude by presenting the scale of attention to diversity beliefs, attitudes, and practices for university teachers (CAPA-PU) (see Appendix). This is a reliable, validated instrument, which is scarce in our country in the case of university faculties. It can be used:

- by university institutions to learn more about the beliefs of university faculty members regarding attention to diversity, as well as the attitudes that they show towards it and how they adapt their teaching, practices and research to the diversity of their educational environment and student body. This information makes it possible to achieve full inclusion in the context of university teaching and research, based on the design of teacher training programmes and the improvement of curricular plans for the different degrees (Arias et al., 2016; Márquez, 2019).

- As a tool that allows educators to self-assess their diversity-related attitudes, beliefs and practices in any professional context, so they can plan for transformation and improvement. 
Of course, the evaluation and diagnosis potential of this tool, both from the point of view of the faculty and the perspective of educational institutions, should be complemented with additional studies and with information collected using qualitative procedures.

\section{NOTAS}

1 The study reported in this paper was supported by the Spain's Ministry of Economy, Industry, and Competitiveness, the State Research Agency, and the European Regional Development Fund. Project Attention to diversity and inclusive education at the university.Diagnosis and evaluation of institutionalization indicators (grant number EDU2017-82862-R) 


\section{REFERENCES}

Abal, F. J., Auné, S. E., Lozzia, G. S., \& Attorresi, H. F. (2017). Funcionamiento de la categoría central en ítems de Confianza para la Matemática. Revista Evaluar, 17(2), 18-31. https://doi. org/10.35670/1667-4545.v17.n2.18717

Ainscow, M. (2016). Struggles for Equity in Education. Routledge.

Álamo, M. (2018). Actitudes hacia la diversidad cultural y la identidad en la formación inicial del profesorado. [Tesis doctoral, Universidad de Córdoba].

American Association of Colleges and Universities (2015). Committing to equity and inclusive excellence. A Campus Guide for Self-Study and Planning. Association of American Colleges and Univesities. https://tinyurl.com/y8tq8bbz

Arias, V., Arias, B., Verdugo, M.A., Rubia, M., \& Jenaro, C. (2016). Evaluación de actitudes de los profesionales hacia las personas con discapacidad. Siglo Cero, 47(2), 258, 7-41. https://doi.org/10.14201/ scero2016472741

Bagozzi, R.P., \& Yi, Y. (1988). On the evaluation of structural equation models. Journal of the Academy of Marketing Science, 16(1), 74-94. https://doi. org/10.1007/bf02723327

Baker, K.Q., Boland, K., \& Nowik, C. M. (2012). A campus survey of faculty and student perceptions of persons with disabilities. Journal of Postsecondary Education and Disability, 25(4), 309-329.

Benítez, R., Aguilar, S., \& Sánchez, L. (2019). Una experiencia para atender a la diversidad en la universidad. Márgenes, Revista de Educación de la Universidad de Málaga, O(0), 76-96. https://doi. org/10.24310/mgnmar.v0i0.6230

Bollen, K. A (1989). Structural equations with latent variables. John Wiley \& Sons.

Browne, M.W., \& Cudeck, R. (1992). Alternative ways of assessing model fit. Sociological Methods and Research, 21(2), 230-258. https://doi. org/10.1177/0049124192021002005

Bowles, T.V., \& Brindle, K. A. (2017). Identifying facilitating factors and barriers to improving student retention rates in tertiary teaching courses: a systematic review. Higher Education Research \& Development, 36(5), 903-19. https://doi.org/10.1080/07294360.2016.1 264927

Castro, F., Castañeda, M.T., Ossa, C., Blanco, E., \& Castillo, N. (2017). Validación de la escala de auto adscripción inclusiva en docentes secundarios de Chile. Psicología Educativa, 23(2), 105-113. https://doi. org/10.1016/j.pse.2017.05.003

Chien, C.L., Montjourridès, P., \& Van der Pol, H. (2017). Global trends of access to and equity in postsecondary Education. En A. Mountfore-Zimdars \& N. Harrison, (Eds). Access to Higher Education. Routledge.

Chou, C. P., \& Bentler, P. M. (1995). Estimates and tests in structural equation modeling. In Hoyle, R. H. (Ed.) Structural equation modeling: Concepts, issues and applications (pp. 37-55). SAGE Publications.

Comité Español de Representantes de Personas con discapacidad -CERMI(2019). Resumen de la posición del movimiento CERMI en materia de educación inclusiva. https://tinyurl.com/ yy3gq72p

Echeita, G. (2017). Educación inclusiva. Sonrisas y lágrimas. Aula Abierta, 36, 17-24. https://doi.org/10.17811/ rifie.46.2017.17-24

Feltrero, R. (2012). Igualdad, diversidad y funcionalidad abierta en el diseño de aplicaciones informáticas: hacia una cultura del diseño para todos. Novática, 216, 6-21. 
VALIDATION OF A SCALE OF ATTENTION TO DIVERSITY FOR UNIVERSITY TEACHERS

Ford Foundation (1999). The Ford Foundation Campus Diversity Initiative Survey of Voters on Diversity in Education and an Interview with Edgar Beckham. Equity \& Excellence in Education, 32(2), 17-23. https://doi. org/10.1080/1066568990320204

Fornell, C., \& Larcker, D.F. (1981). Evaluating structural equation models with unobservable variables and measurement error. Journal of Marketing Research, 18(1), 39-50. https://doi.org/10. 1177/002224378101800104

Fundación Universia (2018). Universidad y Discapacidad. IV Estudio sobre el grado de inclusión del sistema universitario español respecto de la realidad de la discapacidad. Fundación Universia.

García, C., Herrera, C., \& Vanegas, C. (2018). Competencias docentes para una pedagogía inclusiva. Consideraciones a partir de la experiencia con formadores de profesores chilenos. Revista Latinoamericana de Educación Inclusiva, 12(2), 149-167. https://doi.org/10.4067/ s0718-73782018000200149

García, M. Buenestado, M., Gutiérrez, P., López, M., \& Naranjo de Arcos, A. (2017). Apuntes para la inclusión en la comunidad universitaria ¿Qué es una Universidad Inclusiva?. University of Córdoba.

González, F., Martín, E., Flores, N., Jenaro, C., Poy, R., \& Gómez-Vela, M. (2013). Inclusión y convivencia escolar: análisis de la formación del profesorado. European Journal of Investigation in Health, Psychology and Education, 3(2), 125-135.

Hernández, M.J., Urrea, M.E., Fernández, A., \& Aparicio, P. (2018). Atención a la diversidad y escuela inclusiva. Las actitudes del futuro profesorado. International Journal of Developmental and Educational Psychology: INFAD. Revista de Psicología, 1(3), 147-156. https://doi.org/10.17060/ijodaep.2018. n1.v3.1244
Kline, R. B. (2005). Principles and practice of structural equation modeling (2nd Ed.). Guilford Publications.

LePeau, L. A., Hurtado, S. S., \& Davis, R. J. (2018). What institutional websites reveal aboutdiversity-related partnerships between academic and student affairs. Innovative Higher Education, 43(2), 125142. https://doi.org/10.1007/s10755-0179412-0

Lizasoain, L., Etxeberria, J., \& Lukas, J.F. (2017). Propuesta de un nuevo cuestionario de evaluación de los profesores de la Universidad del País Vasco. Estudio psicométrico, dimensional y diferencial. Revista Electrónica de Investigación y Evaluación Educativa, 23(2), art. 1. http://doi. org/10.7203/relieve.23.2.10436

Llorent, V. J. \& Álamo, M. (2016). Escala de actitudes hacia la diversidad cultural (ADC) para los futuros docentes. Opción, 32(11), 832-841.

Llorent, V.J. \& Álamo, M. (2019). La formación inicial del profesorado en las actitudes hacia la diversidad cultural. Validación de una escala. Papeles de Población, 99, 187-208.

Loehlin, J. C., \& Beaujean, A. A. (2017). Latent variable models: An introduction to factor, path, and structural equation analysis. Taylor \& Francis. https://doi. org/10.4324/9781315643199

Lombardi, A. R., Murray, C., \& Gerdes, H. (2011). College faculty and inclusive instruction: Self-reported attitudes and actions pertaining to Universal Design. Journal of Diversity in Higher Education, 4(4), 250-261. https://doi.org/10.1037/ a0024961

Márquez, C. (Ed.) (2019). ¿Avanzamos hacia universidades más inclusivas? De la retórica a los hechos. Dykinson.

Márquez, C., \& Sandoval, M. (2019). Claves para hacer realidad la educación inclusiva en las Universidades. In C. Márquez (Ed.) ¿Avanzamos hacia 
universidades más inclusivas? De la retórica a los hechos (pp. 45-60). Dykinson.

Martins, M.H., Borges, M.L., \& Gonçalves, T. (2018). Attitudes towards inclusion in higher education in a Portuguese university. International Journal of Inclusive Education, 22(5), 527-542. https://doi.org/10.1080/13603116.2017.1 377299

McMahon, S. D., Keys, C. B., Berardi, L., Crouch, R., \& Coker, C. (2016). School inclusion: a multidimensional framework and links with outcomes among urban youth with disabilities. Journal of Community Psychology, 44(5), 656-673. https://doi.org/10.1002/ jcop. 21793

McNair, T. B. (2016). The time is now: Committing to equity and inclusive excellence. Diversity \& Democracy, 19(1). https://aacu.org/ diversitydemocracy/2016/winter/mcnair

Moliner, O., Yazzo, M. A., Niclot, D., \& Philippot, T. (2019). Universidad inclusiva: percepciones de los responsables de los servicios de apoyo a las personas con discapacidad. Revista Electrónica de Investigación Educativa, 21 (20), 1-10. https://doi.org/10.24320/ redie.2019.21.e20.1972

Montero, I., Carneiro, M., Martín, V., Cordero, J., \& Cordero, C. (2019). Objetivos de Desarrollo Sostenible y la promoción de los Derechos de las Personas con Discapacidad. CERMI. Ediciones Cinca. http://riberdis.cedd.net/ handle/11181/5637

Moriña, A. (2017). Inclusive education in higher education: Challenges and opportunities. European Journal of Special Needs Education, 32(1), 3-17 https://doi.org/10.1080/08856257.2016.1 254964

Muntaner Guasp, J. J., Rosselló Ramón, M. R., \& De la Iglesia Mayol, B. (2016).
Buenas prácticas en educación inclusiva. Educatio Siglo XXI, 34(1), 31-49. https:// doi.org/10.6018/j/252521

New England Resource Center for Higher Education (NERCHE) (2016). Self-Assessment Rubric for the Institutionalization of Diversity, Equity and Inclusion in Higher Education. New England Resource Center for Higher Education.

O'Donnell, V.L. (2016). Organisational change and development towards inclusive higher education. Journal of Applied Research in Higher Education, 8(1), 101-118. https://doi.org/10.1108/ JARHE-04-2014-0051

ONU (2018). Informe de la investigación relacionada con España bajo el artículo 6 del Protocolo Facultativo (CRPD/C/20/3). https://bit.ly/3t4hu07

Polo, M. T. (2017). Innovación para la formación en inclusión: actitudes de la comunidad universitaria. International Journal of Developmental and Educational Psychology, 4(1), 185-194. https://doi. org/10.17060/ijodaep.2017.n1.v4.1041

Rodríguez, A., \& Álvarez, E. (2015). Universidad y discapacidad. Actitudes del profesorado y de estudiantes. Perfiles educativos, 37(147). https://doi. org/10.1016/j.pe.2014.09.001

Rodríguez, G., \& Arroyo, D. (Coords.) (2017). Guía de adaptaciones en la universidad. Fundación ONCE.

Simón, C., \& Carballo, R. (2019). Educación inclusiva en la universidad: el papel del profesorado. In Márquez, C. (Ed.) ¿Avanzamos hacia universidades más inclusivas? De la retórica a los hechos (pp. 99-120). Dykinson.

Tanaka, J. S., \& Huba, G. H. (1989). A general coefficient of determination for covariance structure models under arbitrary GLS estimation. British Journal of Mathematical and Statistical Psychology, 42(2), 233-239. 
Toboso, M., Feltero, R., \& Aparicio, M. (2019). Educación inclusiva y educación para la inclusión: transformaciones pendientes analizadas desde las ideas de justicia y accesibilidad universal. In M. Lagarreta (Coord.), I. Ceballos (Coord.) \& S. Carrascal (Dir.) Educación y transformación social y cultural (pp. 185-196). Universitas.

Tomas, J.M., \& Oliver, A. (1998). Efectos de formato de respuesta y método de estimación en análisis factorial confirmatorio. Psicothema, 10(1), 197-208.

UNESCO (2016). Educación 2030: Declaración de Incheon y Marco de Acción para la realización del Objetivo de Desarrollo Sostenible 4: Garantizar una educación inclusiva y equitativa de calidad y promover oportunidades de aprendizaje permanente para todos. ttps:// tinyurl.com/y4g9qpox

Yu, B., \& Zhang, K. (2016). It's more foreign than a foreign country: adaptation and experience of Mainland Chinese students in Hong Kong. Tertiary Education and Management, 22(4), 30015. https://doi.org/10.1080/13583883.201 6.1226944

Yuknis, C. (2015). Attitudes of pre-service teachers toward inclusion for students who are deaf. Deafness \& Education International, 17(4), 183-193. https://doi. org/10.1179/1557069X15Y.0000000003 


\section{APPENDIX}

Scale of Beliefs, Attitudes and Practices of Attention to Diversity for University Teachers (CAPA-PU)

\section{Conception of Diversity}

1

2

3

5

1. The concept of diversity means different ethnicity, race, nationality or culture

2. Diversity means people with different thoughts or ideas

3. The diversity concept means a different education level

\section{Institutional Diversity}

1

$\begin{array}{llll}2 & 3 & 4 & 5\end{array}$

4. Diversity, inclusion and equity are an essential part of education that should be attended to at all university institutions

5. Diversity, inclusion and equity are an institutional but also individual matter, of each member of the institution

6. University curricula should include subjects on the role of women and minorities in the development of societies

7. It is as important for universities to prepare students to be successful in a diverse world as it is to prepare them to have technical or academic skills

8. Universities should develop specific schemes to attend to diversity in the student body

$\begin{array}{lllllll}\text { Diverse Teaching and Learning Practices } & 1 & 2 & 3 & 4 & 5\end{array}$

9. I provide support to help my students to develop individualised plans to facilitate learning

10. I include different teaching and learning methods in my classes to attend to the diversity of the student body

11. I offer resources to respond to the needs of students and attend to the development of inclusive education

12. In my subjects I use digital learning and/or cooperative activities to promote learning for students with diverse needs 
Research, Training and Teaching Focused on Diversity

$\begin{array}{llll}1 & 2 & 3 & 4\end{array}$

5

13. I develop research that in form and/or content reflect my commitment to diversity, inclusion and equity as an added value to the research project

14. In my research designs I include elements that promote diversity, inclusion and equity of cultures, gender, age, etc.

15. I design teaching innovation projects that incorporate issues of attention to diversity of gender, age, culture, religion, etc.

16. I design teaching objectives focused on diversity, inclusion and equity

$\begin{array}{lllllll}\text { University Administrators' Commitment } & 1 & 2 & 3 & 4 & 5\end{array}$

17. In general, university administrators promote schemes for attention to diversity, inclusion and equity

18. In my university, there is a solid trend towards diversity, inclusion and equity in its curriculum.

19. My university offers training courses related to diversity, inclusion and equity

Note. Scale 1 = Strongly disagree; 2 = Agree; 3 = Neither disagree nor agree; 4 = Agree; $5=$ Strongly agree 


\title{
PERFIL ACADÉMICO Y PROFESIONAL DE LAS AUTORAS
}

\author{
Genoveva Ramos Santana. ORCID: https://orcid.org/0000-0002-6931-8725
}

Doctora en Filosofía y CC. de la Educación por la Universitat de València. Profesora Titular del departamento Métodos de Investigación y Diagnóstico en Educación (M.I.D.E.) de la Universitat de València. Sus investigaciones abordan el diseño y validación de escalas de medida; diagnóstico e intervención en altas capacidades y proyectos relacionados con la perspectiva de género en la docencia universitaria. Pertenece al grupo de investigación diversidad y evaluación en la formación a lo largo de la vida (DIVFOREVA) de la Universitat de València. E-mail: genoveva.ramos@uv.es

Amparo Pérez Carbonell. ORCID: https://orcid.org/0000-0002-3537-0293

Doctora en Filosofía y CC. de la Educación por la Universitat de València. Profesora Titular del departamento Métodos de Investigación y Diagnóstico en Educación (M.I.D.E.) de la Universitat de València. En los últimos años centra su investigación y docencia en Evaluación, Atención a la Diversidad e Igualdad de género. Pertenece al grupo de investigación DIVFOREVA-UV. E-mail: amparo.perez@uv.es

Inmaculada Chiva Sanchis. ORCID: https://orcid.org/0000-0002-7145-2309

Doctora en Filosofía y CC. de la Educación por la Universitat de València. Profesora Titular Universidad del Área de Métodos de Investigación y Diagnóstico en Educación de la Universitat de València. Principales líneas de trabajo: evaluación de programas, estudios sobre la calidad de Primaria y Secundaria, formación docente, diseño de instrumentos, e-evaluación de estudiantes universitarios, atención a la diversidad... Pertenece al grupo de investigación DIVFOREVA-UV. E-mail: inmaculada.chiva@uv.es

Ana María Moral Mora. ORCID: https:/orcid.org/0000-0002-6073-3121

Doctora en Pedagogía por la Universitat de València. Profesora Ayudante Doctora del departamento de Métodos de Investigación y Diagnóstico en Educación. Líneas de investigación centradas en: diagnóstico y atención a la diversidad, concretamente en la perspectiva de género en la docencia universitaria, el diagnóstico e intervención en las altas capacidades y la convivencia en entornos educativos. Pertenece al grupo de investigación DIVFOREVA-UV.E-mail: ana.moral@uv.es

Fecha Recepción del Artículo: 09. Octubre. 2020

Fecha Modificación del Artículo: 24. Enero. 2021

Fecha Aceptación del Artículo: 25. Enero. 2021

Fecha Revisión para Publicación: 23. Febrero. 2021 